\title{
Beneficial effects of melatonin and alpha lipoic acid on lopinavir/ ritonavir-induced alterations in serum lipid and glucose levels of male albino rats
}

\author{
Elias Adikwu*, Brambaifa Nelson, Wolfe Atuboyedia Obianime \\ Department of Pharmacology, Faculty of Basic Medical Sciences, University of Port Harcourt, \\ Choba, Rivers State Nigeria
}

Received: January 2016; Accepted: March 2016

\begin{abstract}
The use of lopinavir/ritonavir (LPV/r) has been associated with alterations in serum lipid and glucose levels. This study was designed to investigate the effects of melatonin (MT) and alpha lipoic acid (ALA) on LPV/r-induced changes in serum levels of triglycerides (TG), total cholesterol (TC), low density lipoprotein cholesterol (LDL-C), very low density lipoprotein cholesterol (VLDL-C) and glucose (GL) levels in male albino rats. Rats in group A1 (placebo control) and group A2 (solvent control) were orally treated with normal saline and 1\% ethanol respectively. Groups B-F contained 15 rats each which were divided into 3 groups of 5 rats each. Rats in group B were orally treated with MT (10 mg kg-1/day), ALA (10 mg kg-1/day) and a combination of MT and ALA, accordingly. Rats in group C were orally treated with 22.9/5.71, 45.6/11.4 and 91.4/22.9 mg kg$/ 1 /$ day of LPV/r, accordingly. Rats in groups D-F were orally treated with MT (10 mg kg-1/ day), ALA (10 mg kg-1/day) and combined doses of ALA and MT before oral treatment with 22.9/5.71, 45.6/11.4 and 91.4/22.9 mg kg-1/day of LPV/r, accordingly. All rats were treated for 30 days and at the end of the drug treatment, the serum levels of lipid fractions and glucose were evaluated. Treatment with MT and ALA significantly $(\mathrm{p}<0.05)$ decreased baseline serum levels of TG, TC, VLDL-C, LDL-C and GL, but these parameters were significantly $(\mathrm{p}<0.05)$ increased in a dose-dependent manner in LPV/r-treated rats when compared to placebo control. Administration of MT and ALA prior to treatment with LPV/r significantly $(p<0.05)$ decreased serum levels of TG, TC, VLDL-C, LDL-C and GL when compared to LPV/r-treated rats. However, decreases obtained in rats pretreated with combined doses of MT and ALA were significantly $(\mathrm{p}<0.05)$ different when compared to their individual doses. This study showed that MT and ALA can serve as remedies for LPV/r-induced alterations in serum lipid and glucose levels.
\end{abstract}

Key words: lopinavir/ritonavir, melatonin, alpha lipoic acid, lipid, glucose, rats

\section{Introduction}

Highly active antiretroviral therapy (HAART) involves a combination of three or four classes of antiretroviral drugs. The combination may include two nucleoside analogue reverse transcriptase inhibitors (NRTIs)and one or two protease inhibitors (PIs), or non-nucleoside reverse

\footnotetext{
* adikwuelias@gmail.com

$+234(0) 7068568868$
}

transcriptase inhibitors (NNRTIs) and cell membrane fusion inhibitors (BHIVA, 2014; Lenhard et al., 2000). The use of HAART has improved survival among people living with human immunodeficiency virus (HIV) with significant decrease in morbidity and mortality due to HIV(Wynn et al., 2004). However, the uses of antiretroviral drugs have been associated with alterations in plasma lipid and glucose levels, which could precipitate adverse cardiovascular events (Grunfeld et al., 2010; Haubrich et al., 2009). 
Among the classes of antiretroviral drugs, alterations in plasma lipids and glucose levels are frequent class-related adverse effect of protease inhibitors which could limit their uses, especially in patients with pre-existing cardiovascular risk. Among the protease inhibitors, higher and frequent incidence of alterations in plasma lipid and glucose levels may be common with the use of lopinavir/ ritonavir(LPV/r) (Eron et al., 2006; Hill et al., 2009). Studies have shown that alterations in plasma lipids with LPV/r therapy could be characterized primarily by two factors: elevated plasma triglycerides (TG), and decreased HDLcholesterol (HDL-C). Also, increases in total cholesterol (TC) and low density lipoprotein cholesterol (LDL-C) were frequently observed with LPV/r use (Mulligan et al., 2008). Alterations in serum glucose (GL) and lipid levels could involve oxidative stress. In addition, higher serum levels of malondialdehyde have been reported in subjects with hyperlipidemia (Minhajuddinet al., 2005).

Melatonin (MT) is an indoleamine hormone secreted by the pineal gland of all mammals which is under the control of the central nervous system via the suprachiasmatic nucleus (SCN) of the hypothalamus (Altun et al., 2002). It is a lipophilic and hydrophilic antioxidant with anti-inflammatory property. It inhibits oxidative stress by directly scavenging and neutralizing free radicals and stimulating the activities of other antioxidants (Tan et al., 2011). It influences a variety of biological processes including circadian rhythms, neuroendocrine, cardiovascular and immune functions, as well as thermoregulation (Peschke, 2008). Studies have shown that biological effects of MT also include regulation of insulin secretion and glucose/lipid metabolism (Peschke and Muhlbauer, 2010). MT treatment was observed to markedly improved insulin sensitivity and glucose tolerance in mice on a high-fat diet (Sartoriet al., 2009). It increased hepatic glycogen and improved liver steatosis in high-fat diet-induced diabetic mice (Shieh et al., 2009). Also, it reduced serum TC, LDL-C levels and remarkably increased HDL-C level in high fat diet-induced hyperlipidemia (Hoyos et al., 2000; Nishida et al., 2002).

Alpha lipoic acid (ALA) is a cofactor of $\alpha$-ketoacid dehydrogenase complexes which has antioxidant, anti-inflammatory and immunomudulatory properties and plays a fundamental role in metabolism. ALA and its metabolite (dihydrolipoic acid) are amphipathic molecules that can inhibit oxidative stress by scavenging free radicals in hydrophilic and lipophilic environments and can stimulate the activities of other antioxidants (Wada et al., 1997). It has been found to affect cellular metabolic processes, alter redox status of cells, and interact with thiols and other antioxidants. It is an essential cofactor of mitochondrial respiratory enzymes, including the pyruvate dehydrogenase (PDH) complex with beneficial effects on energy production (Parker et al., 2001). ALA was reported to regulate lipid and glucose metabolism with decrease in insulin resistance in ratsfed with a high fat diet (Seo et al., 2012). It ameliorated streptozotocin-induced alterations in lip$\mathrm{id}$, glucose and insulin levels and oxidative stress indices in rats (Morakinyo et al., 2013). Due to the regulatory effects of MT and ALA on lipid and glucose metabolism, this study investigated the effects of pretreatments with MT and ALA on baseline and LPV/r-induced serum levels of TG, TC, LDL-C, VLDL-C and GL levels in male albino rats.

\section{Materials and methods}

\section{Animals}

Eighty-five male albino rats used for this study were obtained from the animal house of the University of Port Harcourt, Choba, Rivers State.The rats were housed in individual cages at $21 \pm 2{ }^{\circ} \mathrm{C}, 40-60 \%$ relative humidity and exposed to a 12-h light-dark cycle, with the light cycle coinciding with daylight hours. The rats were allowed free access to food and water ad libitum.

Drugs

LPV/r used for this study was manufactured by Myland Laboratories Limited India. The pure samples of MT and ALA used were supplied by Shijiazhuang AO Pharm Import and Export Co Ltd China. All other chemicals used for this study were of analytical grade.

\section{Dose selection}

LPV/r (22.9/5.71, 45.6/11.4 and 91.4/22.9 $\mathrm{mg} \mathrm{kg}^{-1}$ day) which represent 2,4 and 8 times the clinical dose (Hullet al., 2009), MT (10 $\mathrm{mg} \mathrm{kg}^{-1} /$ day) and ALA (10 mg $\mathrm{kg}^{-1} /$ day) were used for this study (Ali, 2013; Bilginoğlu et al., 2014). LPV/r was dissolved in 1\% ethanol; ALA was dissolved in water while MT was dissolve in $1 \%$ ethanol and diluted with normal saline (Reyskens et al., 2013; Shagirtha et al., 2011).

\section{Experimental design}

Grouping of animals: Rats were divided into six groups A-F. Group A which severed as the control contained 10 rats which were sub-divided into two groups: A1 and A2 of 5 animals each. Groups B-F, containing 15 rats each, were sub-divided into 3 groups of 5 animals each.

\section{Control groups}

Rats in group A1 (placebo control) and group A2 (solvent control) were orally treated with $0.2 \mathrm{ml}$ of normal saline and $1 \%$ ethanol respectively.

\section{Antioxidants treated groups}

Rats in group B1-B3 were orally treated with $10 \mathrm{mg}$ $\mathrm{kg}^{-1} /$ day of MT, $10 \mathrm{mg} \mathrm{kg}^{-1} /$ day of ALA, and combined doses of MT and ALA for 30 days. 


\section{Lopinavir/ritonavir treated groups}

Rats in groups C1-C3 were orally treated with 22.9/5.71, 45.6/11.4 94 and 91.4/22.9 mg kg-1/day of $\mathrm{LPV} / \mathrm{r}$ for 30 days respectively.

\section{Lopinavir/ritonavir and antioxidants treated groups}

Rats in groups D1-D3 were orally administered with 10 mg kg-1/day of MT prior to oral treatment with 22.9/5.71, 45.6/11.4 and 91.4/22.9 mg kg-1/day of LPV/r for 30 days respectively.

Rats in groups E1-E3 were orally administered with 10 mg kg-1/day of ALA, prior to oral treatment with 22.9/5.71, 45.6/11.4 and 91.4/22.9 $\mathrm{mg} \mathrm{kg}_{-1} /$ day of LPV/r for 30 days respectively.

Rats in groups F1-F3 were orally administered with combined doses of MT and ALA prior to oral treatment with 22.9/5.71, 45.6/11.4 and 91.4/22.9 mg kg-1/day of $\mathrm{LPV} / \mathrm{r}$ for 30 days respectively.

\section{Collection of samples}

Rats were sacrificed using diethyl ether after day 30 days of treatment. Blood samples were collected via cardiac puncture and transferred into sterile sample containers. The blood samples were allowed to clot, centrifuged at $1200 \mathrm{rpm}$ for $15 \mathrm{~min}$ and serum was extracted and evaluated for lipid profile.

\section{Evaluation of serum lipidand glucose levels}

Serum TG, TC, LDL-C and VLDL-C levels were evaluated as reported by Afolabi et al. (2012). Blood glucose level was evaluated with the aid of one touch basic meter (Lifescan, Inc., 2001 Milpitas, CA 95035, USA) (Tende et al., 2011).

\section{Statistical analysis}

Statistical analysis was performed using Graph pad prism 5 statistical package and ANOVA for comparison of the mean of the various groups. Results are expressed as mean \pm standard error of mean (S.E.M). Statistical significance was set at $\mathrm{p}<0.05$.

\section{Results}

Treatment with individual doses of MT and ALA insignificantly $(p<0.05)$ decreased baseline serum levels of TC, TG, LDL-C, VDL-C and GL when compared to control. Pronounced and significant $(\mathrm{p}<0.05)$ decreases in $\mathrm{TC}$, TG, LDL-C, VDL-C and GL to $48.10 \pm 2.92,35.95 \pm 1.21$, $10.10 \pm 0.02,8.35 \pm 0.50$ and $40.00 \pm 3.00 \mathrm{mg} / \mathrm{dl} \mathrm{respec}-$ tively were obtained in rats treated with a combination of MT and ALA when compared to control (Table 1). On the contrary, treatment with 22.9/5.71-91.4/22.9 $\mathrm{mg} \mathrm{kg}^{-1} /$ day of LPV/r significantly $(\mathrm{p}<0.05)$ and in a dose-dependent manner increased serum levels of TC, TG, LDL-C, VDL$\mathrm{C}$ and GL when compared to control. This study obtained maximum increases in the serum levels of TC, TG, LDL$\mathrm{C}$, VDL-C and GL to $137.3 \pm 4.85,120.3 \pm 5.62,56.88$ $\pm 3.01,43.88 \pm 3.03$ and $110.25 \pm 5.35 \mathrm{mg} / \mathrm{dl}$ respectively in rats treated with $91.4 / 22.9 \mathrm{mg} \mathrm{kg}^{-1} /$ day of $\mathrm{LPV} / \mathrm{r}$ for 30 days (Tables 2-6). Interestingly, pretreatments with individual doses of MT and ALA prior to treatment with 22.9/5.71 -91.4/22.9 $\mathrm{mg} \mathrm{kg}^{-1} /$ day of LPV/r decreased serum levels of TC, TG, LDL-C, VDL-C and GL when compared to serum values obtained in LPV/r treated rats. Most pronounced decreases in the serum levels of TC, TG, LDL$\mathrm{C}, \mathrm{VDL}-\mathrm{C}$ and GL were obtained in rats pretreated with a combination of ALA and MT. Serum values obtained with pretreatment using combined doses of MT and ALA were significantly $(p<0.05)$ different when compared to serum values obtained with pretreatment using individual doses of MT and ALA (Tables 2-6).

\section{Discussion}

The uses of antiretroviral drugs have efficiently suppressed human immunodeficiency virus (HIV) replication, but long-term uses could be associated with alterations in serum lipid and glucose levels. These alterations are major risk factors for the development of cardiovascular diseases and are common among protease inhibitors. Studies have shown that increased TC and TG levels are independent risk factors that can accelerate the development of atherosclerosis and progression of atherosclerotic lesions (Estrada and Portilla, 2011). This study investigated the effects

Table 1. Effects of treatments with MT and ALA on baseline serum lipid and glucose levels of male albino rats

\begin{tabular}{lccccc}
\hline \hline & \multicolumn{4}{c}{ Serum lipid and glucose (mg/dl) } \\
Dose & TG & TC & LDL-C & VLDL-C & GL \\
\hline Control (placebo) & $45.33 \pm 2.35$ & $66.55 \pm 4.74$ & $16.20 \pm 1.65$ & $12.30 \pm 0.34$ & $50.75 \pm 4.57$ \\
MT $(10 \mathrm{mg} / \mathrm{kg})$ & $44.15 \pm 3.00$ & $60.43 \pm 4.38$ & $14.41 \pm 0.67$ & $12.88 \pm 0.67$ & $48.40 \pm 0.51$ \\
ALA $(10 \mathrm{mg} / \mathrm{kg})$ & $43.10 \pm 3.22$ & $60.38 \pm 3.37$ & $14.30 \pm 0.55$ & $10.33 \pm 1.50$ & $47.08 \pm 3.50$ \\
MT+ALA & $35.95 \pm 1.21 *$ & $48.10 \pm 2.92 *$ & $10.10 \pm 0.02 *$ & $8.35 \pm 0.50 *$ & $40.00 \pm 3.00^{*}$ \\
\hline
\end{tabular}

$\mathrm{MT}=$ Melatonin $\mathrm{ALA}=$ Alphalipoic acid. Results are expressed as mean \pm S.E.M.

* Significant $(\mathrm{p}<0.05)$ difference when compared to control 
Table 2. Effects of MT and ALA on lopinavir/ritonavir-induced serum level of triglyceridesin male albino rats

\begin{tabular}{lcccc}
\hline & \multicolumn{3}{c}{ Serum triglyceride $(\mathrm{mg} / \mathrm{dl})$} \\
Dose $(\mathrm{mg} / \mathrm{kg})$ & $\mathrm{LPV} / \mathrm{r}$ & $\mathrm{MT}+\mathrm{LVP} / \mathrm{r}$ & $\mathrm{ALA}+\mathrm{LVP} / \mathrm{r}$ & MT+ALA+LPV/r \\
\hline Control & $45.33 \pm 4.35$ & $45.33 \pm 4.35$ & $45.33 \pm 4.35$ & $45.33 \pm 4.35$ \\
$22.9 / 5.71$ & $63.45 \pm 3.65$ & $46.18 \pm 2.86^{*}$ & $48.95 \pm 1.03^{*}$ & $35.88 \pm 2.67^{* *}$ \\
$45.6 / 11.4$ & $82.53 \pm 4.88$ & $48.13 \pm 2.16^{*}$ & $50.00 \pm 3.78^{*}$ & $38.33 \pm 1.50^{* *}$ \\
$91.4 / 22.9$ & $120.3 \pm 5.62$ & $70.40 \pm 3.71^{*}$ & $71.45 \pm 5.08^{*}$ & $40.35 \pm 3.50^{* *}$ \\
\hline
\end{tabular}

$\mathrm{LPV} / \mathrm{r}=$ Lopinavir/ritonavir, $\mathrm{MT}=$ Melatonin, ALA $=$ Alphalipoic acid. Results are expressed as mean \pm S.E.M.

*Significant $(\mathrm{p}<0.05)$ difference when compared to treatment with LPV/r

** Significant $(\mathrm{p}<0.05)$ difference when compared to pretreatments with individual doses of MT and ALA

Table 3. Effects of MT and ALA on lopinavir/ritonavir-induced serum level of total cholesterol in male albino rats

\begin{tabular}{lcccc}
\hline \hline & \multicolumn{3}{c}{ Serum total cholesterol (mg/dl) } \\
Dose $(\mathrm{mg} / \mathrm{kg})$ & $\mathrm{LPV} / \mathrm{r}$ & $\mathrm{MT}+\mathrm{LVP} / \mathrm{r}$ & ALA+LVP/r & MT+ALA+LPV/r \\
\hline Control & $66.55 \pm 3.74$ & $66.55 \pm 3.74$ & $66.55 \pm 3.74$ & $66.55 \pm 3.74$ \\
$22.9 / 5.71$ & $98.75 \pm 4.70$ & $65.68 \pm 3.05^{*}$ & $68.68 \pm 4.42^{*}$ & $50.20 \pm 3.78^{* *}$ \\
$45.6 / 11.4$ & $123.0 \pm 5.04$ & $70.30 \pm 4.37^{*}$ & $74.5 \pm 5.19^{*}$ & $55.20 \pm 2.17^{* *}$ \\
$91.4 / 22.9$ & $137.3 \pm 4.85$ & $80.02 \pm 4.47^{*}$ & $85.5 \pm 2.70^{*}$ & $57.55 \pm 3.07^{* *}$ \\
\hline
\end{tabular}

$\mathrm{LPV} / \mathrm{r}=$ Lopinavir/ritonavir, MT $=$ Melatonin, ALA $=$ Alphalipoic acid. Results are expressed as mean \pm S.E.M.

*Significant $(\mathrm{p}<0.05)$ difference when compared to treatment with LPV/r

** Significant $(\mathrm{p}<0.05)$ difference when compared to pretreatments with individual doses of MT and ALA

Table 4. Effects of MT and ALA on lopinavir/ritonavir-induced serum level of low density lipoprotein cholesterol in male albino rats

\begin{tabular}{|c|c|c|c|c|}
\hline \multicolumn{5}{|c|}{ Low density lipoprotein cholesterol $(\mathrm{mg} / \mathrm{dl})$} \\
\hline Dose $(\mathrm{mg} / \mathrm{kg})$ & $\mathrm{LPV} / \mathrm{r}$ & $\mathrm{MT}+\mathrm{LVP} / \mathrm{r}$ & $\mathrm{ALA}+\mathrm{LVP} / \mathrm{r}$ & $\mathrm{MT}+\mathrm{ALA}+\mathrm{LPV} / \mathrm{r}$ \\
\hline Control & $16.20 \pm 0.65$ & $16.20 \pm 0.65$ & $16.20 \pm 0.65$ & $16.20 \pm 0.65$ \\
\hline $22.9 / 5.71$ & $32.90 \pm 1.89$ & $18.53 \pm 1.86^{*}$ & $20.33 \pm 1.25^{*}$ & $10.56 \pm 0.59 * *$ \\
\hline $45.6 / 11.4$ & $47.20 \pm 3.70$ & $21.43 \pm 1.61 *$ & $23.05 \pm 1.93 *$ & $12.68 \pm 0.30^{* *}$ \\
\hline $91.4 / 22.9$ & $56.88 \pm 3.01$ & $22.38 \pm 1.36^{*}$ & $25.53 \pm 1.58^{*}$ & $12.90 \pm 0.58^{* *}$ \\
\hline
\end{tabular}

$\mathrm{LPV} / \mathrm{r}=$ Lopinavir/ritonavir, $\mathrm{MT}=$ Melatonin, $\mathrm{ALA}=$ Alphalipoic acid. Results are expressed as mean \pm S.E.M.

* Significant $(\mathrm{p}<0.05)$ difference when compared to treatment with $\mathrm{LPV} / \mathrm{r}$

** Significant $(\mathrm{p}<0.05)$ difference when compared to pretreatments with individual doses of MT and ALA

Table 5. Effects of MT and ALA on lopinavir/ritonavir-induced serum level of very low density lipoprotein cholesterol in male albino rats

\begin{tabular}{|c|c|c|c|c|}
\hline \multicolumn{5}{|c|}{ Very low density lipoprotein cholesterol $(\mathrm{mg} / \mathrm{dl})$} \\
\hline Dose $(\mathrm{mg} / \mathrm{kg})$ & $\mathrm{LPV} / \mathrm{r}$ & $\mathrm{MT}+\mathrm{LVP} / \mathrm{r}$ & $\mathrm{ALA}+\mathrm{LVP} / \mathrm{r}$ & $\mathrm{MT}+\mathrm{ALA}+\mathrm{LPV} / \mathrm{r}$ \\
\hline Control & $12.23 \pm 0.34$ & $12.30 \pm 0.34$ & $12.30 \pm 0.34$ & $12.30 \pm 0.34$ \\
\hline $22.9 / 5.71$ & $24.90 \pm 0.52$ & $15.01 \pm 1.06^{*}$ & $17.31 \pm 1.07^{*}$ & $10.31 \pm 2.18^{* *}$ \\
\hline $45.6 / 11.4$ & $35.20 \pm 2.64$ & $16.22 \pm 0.37 *$ & $20.23 \pm 1.01 *$ & $11.05 \pm 1.32 * *$ \\
\hline $91.4 / 22.9$ & $43.88 \pm 3.03$ & $22.12 \pm 1.21 *$ & $25.71 \pm 2.09 *$ & $14.42 \pm 0.04 * *$ \\
\hline
\end{tabular}

$\mathrm{LPV} / \mathrm{r}=$ Lopinavir/ritonavir, MT= Melatonin, $\mathrm{ALA}=$ Alpha lipoic acid. Results are expressed as mean \pm S.E.M.

* Significant $(p<0.05)$ difference when compared to treatment with LPV/r

** Significant $(\mathrm{p}<0.05)$ difference when compared to pretreatments with individual doses of MT and ALA 
Table 6. Effects of MT and ALA on lopinavir/ritonavir-induced serum level of glucose in male albino rats

\begin{tabular}{lcccc}
\hline \hline & & Glucose $(\mathrm{mg} / \mathrm{dl})$ & & \\
Dose $(\mathrm{mg} / \mathrm{kg})$ & LPV/r & MT+LVP/r & ALA+LVP/r & MT+ALA+LPV/r \\
\hline Control & $50.75 \pm 3.47$ & $50.75 \pm 3.47$ & $50.75 \pm 3.47$ & $50.75 \pm 3.47$ \\
$22.9 / 5.71$ & $71.00 \pm 2.70$ & $49.00 \pm 2.70^{*}$ & $51.00 \pm 2.81^{*}$ & $30.25 \pm 2.75^{* *}$ \\
$45.6 / 11.4$ & $82.25 \pm 4.62$ & $51.25 \pm 1.37 *$ & $50.00 \pm 2.40^{*}$ & $30.75 \pm 2.85^{* *}$ \\
$91.4 / 22.9$ & $110.25 \pm 5.35$ & $64.50 \pm 3.25^{*}$ & $66.25 \pm 4.75^{*}$ & $32.35 \pm 1.10^{* *}$ \\
\hline
\end{tabular}

$\mathrm{LPV} / \mathrm{r}=$ Lopinavir/ritonavir, MT = Melatonin, ALA = Alphalipoic acid. Results are expressed as Mean \pm S.E.M.

*Significant $(\mathrm{p}<0.05)$ difference when compared to treatment with LPV/r

** Significant $(\mathrm{p}<0.05)$ difference when compared to pretreatments with individual doses of MT and ALA

of pretreatments with MT and ALA on LPV/r-induced serum levels of TC, TG, LDL-C, VLDL-C and GL in male albino rats. The effects of treatment with MT and ALA on baseline serum levels of the above parameters were also evaluated.

In the present study, treatment with individual doses of MT and ALA decreased baseline serum levels of TC, TG, LDL-C, VLDLC, and GL with most pronounced decreases obtained in rats treated with combined doses of MT and ALA.This observation is consistent with the work of Hussain et al. (2015) who treated rats with ALA for 3-6 weeks and reported decreases in serum lipid and glucose levels. Also, Scacchi et al. (2013) reported decreases in serum lipid and glucose levels in rats administered with MT which support our findings. On the other hand, treatment with $\mathrm{LPV} / \mathrm{r}$ in a dose-dependent manner increased serum levels of TC, TG, LDL-C, VLDL-Cand GL. This observation is in agreement with the work of Pistell et al. (2010), who treated mice with $\mathrm{LPV} / \mathrm{r}$ and reported increases in lipid and glucose levels. Also, Canavaghi et al. (2012) administered $30 \mathrm{mg} / \mathrm{kg}$ ritonavir and reported increases in serum lipid and glucose levels which support observations in the present study. However, pretreatment with MT and ALA prior to treatment with $\mathrm{LPV} / \mathrm{r}$ decreased serum levels of TC, TG, LDL-C, VLDL-C, and GL with most pronounced decreases obtained in rats pretreated with combined doses of MT and ALA. In the present study, observed increases inlipid parameters could be attributed to LPV/r-induced increases in fatty acid and cholesterol synthesis in the liver and adipose tissue caused by activation of sterol regulatory element binding protein (SREBP) 1 and 2. Another possible mechanism is the inhibition of lipoprotein lipase and lecithin cholesterol acyltransferase (LCAT) clearance of triglyceride-rich lipoprotein remnants by LPV/r. Furthermore, LPV/r can up-regulate the activity of hydroxymethyl-glutaryl-COA (HMG-CoA) reductase, there-by increasing lipoprotein synthesis (Carpentier et al., 2005; Lenhard et al., 2000; Riddle et al., 2001). Studies in cultured liver cells suggest that LPV/r-induced elevation in lipid levels could be associated to the inhibition of $20 \mathrm{~S}$ proteasome leading to decreased degradation of nascent apolipoprotein B (Liang et al., 2001). The observed increases in glucose levels in LPV/r treated rats could be attributed to the inhibition of glucose transport mediated by GLUT-4, which is the predominant transporter involved in insulin-stimulated cellular uptake of glucose in humans (Murata et al., 2000).

Furthermore, mitigation of LPV/r-induced increases in lipid levels in rats pretreated with ALA could be attributed to reduced HMG-CoA reductase activity and increased activities of lipoprotein lipase and lecithin cholesterol acyl transferase (LCAT) by ALA (Sinclair et al., 1991). Also, it could be attributed to the inhibitory effect of ALA on fatty acid and cholesterol synthesis in the liver and accumulation in skeletal muscles, pancreatic islets and adipose tissue (Lee et al., 2005).. The observed decrease in serum glucose level in rats pretreated with ALA could be attributed to increased cellular uptake of glucose by recruiting GLUT-4 to the cell membrane as observed in cell culture experiments (Henriksen et al., 2006). Some studies reported that treatment with racemic - lipoic acid improved insulin sensitivity and glucose effectiveness by increasing pyruvate transportation into mitochondria which might have increased pyruvate oxidation and in turn, allowed glucose to enter the cytoplasm thereby decreasing insulin resistance (Jacob et al., 1999; Walgren et al., 2004).

The observed decreases in lipid levels in MT pretreated rats could be attributed to the inhibition of cholesterol absorption (Hussein et al., 2007), inhibition of cholesterol synthesis, enhancement of cholesterol catabolism to bile acids and increase in LDL receptors synthesis/activity (Chan and Tang, 1995; Müller-Wieland et al., 1994). It could also suppress visceral fat without affecting subcutaneous deposits, leading to enhanced lipoprotein lipase activity and reduced lipolytic activity in visceral adipose tissue (Rasmussen et al., 1999). In vitro, MT treatment of adipocytes has been shown to inhibit differentiation and limit adipose tissue hypertrophy (Alonso-Vale et al., 2009) thereby preventing fatty acid-induced triglyceride accumulation in cells (Agil et al., 2012; Nduhirabandi et al., 2011; Tamura et al., 2008). MT might have inhibited LPV/r-in- 
duced sterol regulatory element-binding protein (SREBP)$1 \mathrm{c}$, as well as the expression of SREBP- 1c target genes thereby preventing hepatic lipid accumulation (Chen et al., 2011). The observed decrease in GL level in MT pretreated rats could be attributed to the up-regulation of the activities of GLUT-4 (Zanquetta et al., 2003) and increase in GLUT-4 gene expression (Gosh et al., 2007). It has been shown to stimulate GL transport in skeletal muscle and improved glucose homeostasis by restoring the vascular actions of insulin (Ha et al., 2006). In addition, its effect on serum glucose level may be due to its ability to increase insulin output by stimulating pancreatic B-cells (Poon et al., 2001).

Furthermore, studies have associated increases in lipid and glucose levels with oxidative stress via free radical generation (Yang et al., 2008); hence effects of MT and ALA on lipid and glucose levels observed in the present study may be attributed to the antioxidant effects of MT and ALA (Cagnoli et al., 1995; Gitto et al., 2001; Rodriguez et al., 2004; Tan et al., 1994). Furthermore, several MT metabolites (e.g., N1-acetyl-N2-formyl-5-methoxykynuramine (AFMK) which could be formed when MT neutralizes damaging reactants are also free radical scavengers (Reiter and Korkmaz, 2008; Tan et al., 2007).Importantly, MT and ALA treatments could protect against mitochondrial damage there-by preventing the release of reactive oxygen species (Lopez et al., 2009; Paradies et al., 2010). In addition, MT and ALA have anti-inflammatory properties which might have contributed to their regulatory effects on lipid and glucose levels observed in this study (Odabasoğlu et al., 2011; Rodriguez et al., 2007). In the current study, decreases in serum lipid and glucose levels were highly pronounced in rats pretreated with combined doses of MT and ALA which could be attributed to synergy in the activity of MT and ALA (Adikwu et al., 2016).

\section{Conclusion}

This study showed that pretreatment with MT and ALA ameliorated LPV/r-induced increases in serum lipid and glucose levels. Maximum ameliorations were obtained with pretreatment using combined doses of MT and ALA. Based on observations in this study, MT and ALA could be used for the management of LPV/r associated alterations in serum lipid and glucose levels.

\section{Acknowledgements}

The authors appreciate the technical assistance of Mr. Woy Yirupe of the Department of Pharmacology, Faculty of Basic Medical Sciences, University of Port Harcourt, Choba, Rivers State.

\section{Declaration of interest}

The authors report no conflicts of interest. The authors alone are responsible for the content and writing of the article.

\section{References}

Adikwu, E., Braimbaifa, N., Obianime, A.W., 2016. Melatonin and Alpha Lipoic Acid: Possible Mitigants for Lopinavir/ Ritonavir-Induced Renal Toxicity in Male Albino Rats. Physiol. Pharmacol. 19, 232-240.

Afolabi, O.K., Oyewo, E.B., Adekunle, A.S., Adedosu, O.T., Adedeji, A.L.,2012. Impaired lipid evels \& inflammatory response in rats exposed to cadmium. EXCLI Journal 11, 677-687.

Agil, A., Rosado, I., Ruiz, R., Figueroa, A., Zen, N., FernándezVázquez, G., 2012. Melatonin improves glucose homeostasis in young Zucker diabetic fatty rats. J. Pineal Res. 52(2), 203210 .

Ali, W.S., 2013. Comparative study between marjoram and alpha lipoic acid on potassium bromide induced oxidatives stress in rats. Word J. Dairy Food Sci. 8(1), 94-99.

Alonso-Vale, M.I., Peres, S.B., Vernochet, C., Farmer, S.R., Lima, F.B., 2009.Adipocyte differentiation is inhibited by melatonin through the regulation of $\mathrm{C} / \mathrm{EBPbeta}$ transcriptional activity. J. Pineal Res. 47, 221-227.

Altun, A., Yaprak, M., Aktoz, M., Vardar, A., Betul, U.A., Ozbay, G., 2002. Impaired nocturnal synthesis of melatonin in patients with cardiac syndrome X. Neurosci. Lett. 327, 143145 .

Bernasconi, P.A., Cardoso, N.P., Reynoso, R., Scacch,i P., Cardinali, D.P., 2013. Melatonin and diet-induced metabolic syndrome in rats. Impact on the hypophysial-testicular axis. Horm. Mol. Biol. Clin. Investig. 16(2), 101-112.

Bilginoğlu, A., Aydın, D., Özsoy, S., Aygün, H., 2014. Protective effect of melatonin on adriamycin-induced cardiotoxicity in rats. Arch. Turk. Soc. Cardiol. 42(3), 265-273.

BHIVA, 2014. British HIV Association guidelines for the treatment of HIV positive adults with antiretroviral therapy HIV Medicine (2012). Avalilable at: http://www.bhiva.org/ documents/Guidelines/Treatment/2012/hiv1029_2.pdf.

Cagnoli, C.M., Atabay, C., Kharlamova, E., Manev, H., 1995. Melatonin protects neurons from singlet oxygen-induced apoptosis. J. Pineal Res. 18(4), 222-226.

Carpentier, A., Patterson, B.W., Uffelman, K.D., Salit, I., Lewis, G.F., 2005. Mechanism of highly active anti-retroviral therapy-induced hyperlipidemia in HIV-infected individuals. Atherosclerosis 178, 165-172.

Cavenaghi, F.M., Bataglion, C.A.N., Paula, P.C., Motta, A.C.F., Komesu, M.C., 2012.Protease inhibitor and metabolic alteration. Int. J. Morphol. 30(2), 439-444.

Chan, T.Y., Tang, P.L., 1995. Effect of melatonin on the maintenance of cholesterol homeostasis in the rat. Endocr. Res. 21, 681-696.

Chen, X., Zhang, C., Zhao, M., Shi, C.E., Zhu, R.M., Wang, H, Zhao, H., Wei, W., Li, J.B., Xu, D.X., 2011. Melatonin alleviates lipopolysaccharide-induced hepatic SREBP-1c activation and lipid accumulation in mice. J. Pineal Res. 51(4), 416-425.

Eron, J., Yeni, P., Gathe, J., Estrada, V., DeJesus, E., Staszewski, 
S., Lackey, P., Katlama, C., Young, B., Yau, L., SutherlandPhillips, D., Wannamaker, P., Vavro, C., Patel, L., Yeo, J., Shaefer, M., 2006. The Klean study: fosamprenavirritonavir versus lopinavir-ritonavir, each in combination with abacavir-lamivudine, for the initial treatment of HIV infection over 48 weeks: a randomized non-inferiority trial. Lancet 368, 476-482.

Estrada, V., Portilla, J., 2011. Dyslipidemia Related to Antiretroviral Therapy. AIDS Rev. 13, 49-56.

Ghosh, G., De, K., Maity, S., Bandyopadhyay, D., Bhattacharya, S., Reiter, R.J., Bandyopadhyay, A., 2007. Melatonin protects against oxidative damage and restores expression of GLUT4 gene in the hyperthyroid rat heart. J. Pineal Res. 42, 71-82.

Gitto, E., Tan, D.X., Reiter, R.J., Karbownik, M., Manchester, L.C., Cuzzocrea, S., Fulia, F.,Barberi, I., 2001. Individual and synergistic antioxidative actions of melatonin: studies with vitamin $\mathrm{E}$, vitamin $\mathrm{C}$, glutathione and desferrioxamine (desferoxamine) in rat liver homogenates. J. Pharm. Pharmacol. 53, 1393-1401.

Grunfeld, C., 2010. Dyslipidemia and its treatment in HIV infection. Top HIV Med. 18, 112-118.

Ha, E., Yim, S.V., Chung, J.H., Yoon, K.S., Kang, I., Cho, Y.H., Baik, H.H., 2006. Melatonin stimulates glucose transport via insulin receptor substrate-1/phosphatidylinositol 3-kinase pathway in $\mathrm{C} 2 \mathrm{C} 12$ murine skeletal muscle cells. J. Pineal Res. 41, 67-72.

Haubrich, R.H., Riddler, S.A., DiRienzo, A.G., Komarow, L., Powderly, W.G., Klingman, K., Garren, K.W., Butcher, D.L., Rooney, J.F., Haas, D.W., Mellors, J.W., Havlir, D.V., 2009. Metabolic outcomes in a randomized trial of nucleoside, nonnucleoside and protease inhibitor-sparing regimens for initial HIV treatment. AIDS 23(9), 1109-1118.

Henriksen, E.J., 2006. Exercise Training and the antioxidant alpha-lipoic acid in the treatment of insulin resistance and type 2 diabetes. Free Radic. Biol. Med. 40, 3-12.

Hill, A., Sawyer, W., Gazzard, B., 2009. Effects of first-line use of nucleoside analogues, efavirenz, and ritonavir-boosted protease inhibitors on lipid levels. HIV Clin. Trials 10, 1-12.

Hoyos, M., Guerrero, J.M., Perez-Cano, R., Olivan, J., Fabiani, F., Garcia-Pergañeda, A., Osuna, C.,2000. Serum cholesterol and lipid peroxidation are decreased by melatonin in diet-induced hypercholesterolemic rats. J. Pineal Res. 28(3), 150-155.

Hull, M., Harris, W.M., Lima, V.,Guillemi, S., Harrigan, P.R., Montaner, J.S., 2009.Lopinavir/ritonavir pharmacokinetics in a substitution of high-dose soft-gelatin capsule to tablet formulation. J. Clin. Pharmacol. 49, 155-161.

Hussein, S.A., Abdel-mageid, A.D., Abu-ghazalla, A.A., 2015. Biochemical study on the effect of alpha-lipoic acid on lipid metabolism of rats fed high fat diet. Benha Vet. Med. J. 28(1), 109-119.

Hussein, M.R., Ahmed, O.G., Hassan, A.F., Ahmed, M.A., 2007. Intake of melatonin is associated with amelioration of physiological changes, both metabolic and morphological pathologies associated with obesity: an animal model. Int. J. Exp. Pathol. 88(1), 19-29.

Jacob, S., Ruus, P., Hermann, R., Tritschler, H.J., Maerker, E., Renn, W., Augustin, H.J., Dietze, G.J., Rett, K., 1999. Oral administration of RAC-alpha-lipoic acid modulates insulin sensitivity in patients with type 2 diabetes mellitus: a placebo-controlled pilot trial. Free Radio. Biol. Med. 27, 309-314.

Lee, W.J., Song, K. H., Koh, E.H., Won, J.C., Kim, H.S., Park, H. S., Kim, M. S., Kim, S.W., Lee, K.U., Park, J.Y., 2005. A
-Lipoic acid increases insulin sensitivity by activating AMPK in skeletal muscle. Biochem. Biophys. Res. Communi. 332, 885- 891.

Lenhard, J., Croom, D.K., Weiel, J., Winegar, D., 2000. HIV protease inhibitors stimulate hepatic triglyceride synthesis. Arterioscler. Thromb. Vasc. Biol. 20, 2625-2629.

Liang, J.S., Distler, O., Cooper, D.A., Jamil, H., Deckelbaum, R.J., Ginsberg, H.N., Sturley, S.L., 2001. HIV protease inhibitors protect apolipiprotein $\mathrm{B}$ from degradation by the proteasome: a potential mechanism for protease inhibitorinduced hyperlipidemia. Nat. Med. 7, 1327-1331.

Lopez, A., Garcia, J.A., Escames, G., Venegas, C., Ortiz, F., Lopez, L.C., Acuna-Castroviejo, D., 2009. Melatonin protects the mitochondria from oxidative damage reducing oxygen consumption, membrane potential, and superoxide anion production. J. Pineal Res. 46, 188-198.

Minhajuddin, M., 2005. Hypolipidemic and antioxidant properties of tocotrienol rich fraction isolated from rice bran oil in experimentally induced hyperlipidemic rats. Food Chem. Toxicol. 43, 747-753.

Morakinyo, O.A., Awobajo, F.O., Adegoke, O.A., 2013. Effects of alpha lipoic acid on blood lipids, renal indices, antioxidant enzymes, insulin and glucose level in streptozotocin-diabetic rats. Bio. Med. 5, 26-33.

Müller-Wieland, D., Behnke, B., Koopmann, K., Krone, W., 1994. Melatonin inhibits LDL receptor activity and cholesterol synthesis in freshly isolated human mononuclear leukocytes. Biochem. Biophys. Res. Commun. 203, 416-421.

Mulligan, K., Grunfeld, C., Tai, V.W., Algren, H., Pang, M., Chernoff, D.N., Lo, J.C., Schambelan, M., 2000. Hyperlipidemia and insulin resistance are induced by protease inhibitors independent of changes in body composition in patients with HIV infection. J. Acquir. Immune. Defic. Syndr. 23, 35-43.

Murata, H., Hruz, P.W., Mueckler, M., 2002. The mechanism of insulin resistance caused by HIV protease inhibitor therapy. J. Biol. Chem. 275(27), 20251-20254.

Nduhirabandi, F., Du Toit, E.F., Blackhurst, D., Marais, D., Lochner, A., 2011. Chronic melatonin consumption prevents obesity-related metabolic abnormalities and protects the heart against myocardial ischemia and reperfusion injury in a prediabetic model of diet-induced obesity. J. Pineal Res. 50, 171-182.

Nishida, S., Segawa, T., Murai, I., Nakagawa, S., 2002. Longterm melatonin administration reduces hyperinsulinemia and improves the altered fatty-acid compositions in type 2 diabetic rats via the restoration of Delta- 5 desaturase activity. J. Pineal Res. 32(1), 26-33.

Odabasoğlu, F., Halici, Z., Aygun, H., Halici, M., Atalay, F.,

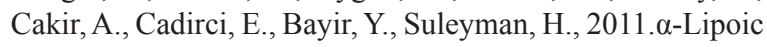
acid has anti-inflammatory and anti-oxidative properties: an experimental study in rats with carrageenan-induced acute and cotton pellet-induced chronic inflammations. Br. J. Nutr. 105, 31-43.

Paradies, G., Petrosillo, G., Paradies, V., Reiter, R.J., Ruggiero, F.M., 2010.Melatonin, cardiolipin and mitochondrial bioenergetics in health and disease. J. Pineal Res. 48, 297310.

Peschke, E., Muhlbauer, E., 2010. New evidence for a role of melatonin in glucose regulation. Best Pract. Res. Clin. Endocrinol. Metab. 24, 829-841.

Peschke, E., 2008. Melatonin, endocrine pancreas and diabetes. J. Pineal Res. 44, 26-40. 
Poon, A.M., Choy, E.H., Pang, S.F., 2001. Modulation of blood glucose by melatonin: a direct action on melatonin receptors in mouse hepatocytes. Biol. Signals Recept. 10, 367-379.

Pistell, PJ., Gupta, S., Knight, A.G., Domingue, M., Uranga, R.M., Ingram, D.K., Kheterpa, I.Ruiz, C., Kelle,r J.N., BruceKeller, A.J., 2010. Metabolic and neurologic consequences of chronic Lopinavir/Ritonavir administration to C57BL/6 mice. Antiviral Res. 88(3), 334-342.

Rasmussen, D.D., Boldt, B.M., Wilkinson, C.W., Yellon, S.M., Matsumoto, A.M., 1999. Daily melatonin administration at middle age suppresses male rat visceral fat, plasma leptin, and plasma insulin to youthful levels. Endocrinology 140, 1009-1012.

Reiter, R.J., Korkmaz, A., 2008. Clinical aspects of melatonin. Saudi. Med. J. 29, 1537-1547.

Reyskens, K.M.S.E., Fisher, T.L., Schisler, J.C., O'Connor, W.G., Rogers, A.B., 2013. Cardio-Metabolic Effects of HIV Protease Inhibitors (Lopinavir/ Ritonavir). PLoS ONE8 8(9), e73347.

Riddle, T.M., Kuhel, DE.G., Woollett, L.A., Fichtenbaum, C.J., Hui D.Y., 2001. HIV protease inhibitor induces fatty acid and sterol biosynthesis in liver and adipose tissues due to the accumulation of activated sterol regulatory element-binding proteins in the nucleus. J. Biol. Chem. 276, 37514-37519.

Rodriguez, M.I., Escames, G., Lopez, L.C., García, J.A., Ortiz, F., Acuña-Castroviejo, D., 2007. Chronic melatonin treatment reduces the age-dependent inflammatory process in senescence-accelerated mice. J. Pineal Res. 42, 272-279.

Rodriguez, C., Mayo, J.C., Sainz, R.M., Antolin, I., Herrera, F., Martin, V., Reiter, R.J., 2004.Regulation of antioxidant enzymes: a significant role for melatonin. J. Pineal Res. 36, $1-9$.

Sartori, C., Dessen, P., Mathieu, C., Monney, A., Bloch, J., Nicod, P., Scherrer, U., Duplain, H., 2009. Melatonin improves glucose homeostasis and endothelial vascular function in highfat diet-fed insulin-resistant mice. Endocrinology 150, 5311-5317.

Seo, E.Y., Ha, A.W., Kim, W.K., 2012. $\alpha$-Lipoic acid reduced weight gain and improved the lipid profile in rats fed with high fat diet. Nutr. Res. Pract. 6(3), 195-200.

Shagirtha, K., Muthumani, M., Prabu, S., 2011. Melatonin abrogates cadmium induced oxidative stress related neurotoxicity in rats. Eur. Rev. Med. Pharmacol. Sci. 15, 1039-1050

Shieh, J.M., Wu, H.T., Cheng, K.C., Cheng, J.T., 2009. Melatonin ameliorates high fat dietinduced diabetes and stimulates glycogen synthesis via a PKCzeta-Akt-GSK3beta pathway in hepatic cells. J. Pineal Res. 47, 339-344.
Sinclair, A.J., Girling, A.J., Gray, L., LeGuen, C., Lunec, J., Barnett, A.H., 1991. Disturbed handling of ascorbic acid in diabetic patients with and without microangiopathy during high dose ascorbate supplementation. Diabetologia 34, 171175.

Tamura, H., Nakamura, Y., Narimatsu, A., Yamagata, Y., Takasaki, A., Reiter, R.J., Sugino, N., 2008. Melatonin treatment in peri- and postmenopausal women elevates serum highdensity lipoprotein cholesterol levels without influencing total cholesterol levels. J. Pineal Res. 45, 101-105.

Pieri, C., Marra, M., Moroni, F., Recchioni, R., Marcheselli, F., 1994. Melatonin: a peroxyl radical scavenger more effective than vitamin E. Life Sci. 55, 271-276.

Tan, D.X., Manchester, L.C., Terron, M.P., Flores, L.J., Reiter, R.J., 2007. One molecule, many derivatives: a never-ending interaction of melatonin with reactive oxygen and nitrogen species? J. Pineal Res. 42, 28-42.

Tende, J.A., Ezekiel, I., Dikko, A.U., Goji, A.D., 2011. Effect of Ethanolic Leaves Extract of Moringaoleifera on Blood Glucose Levels of streptozocin-Induced Diabetics and Normoglycemic Wistar Rats. Br. J. Pharmacol. Toxicol. 2(1), $1-4$.

Wada, H., Shintani, D., Ohlrogge, J., 1997. Why do mitochondria synthesize fatty acids? Evidence for involvement in lipoic acid production. Proc. Natl. Acad. Sci. USA, 94, 1591-1596.

Walgren, J.L., Amani, Z., McMillan, J.M., Locher, M., Buse, M.G., 2004. Effect of R (+) $\alpha$ - lipoic acid on pyruvate metabolism and fatty acid oxidation in rat hepatocytes. Metabolism 53, 165-173.

Wynn, G.H., Zapor, M.J., Smith, B.H., Wortmann, G., Oesterheld, J. R., Armstrong, S. C., Cozza, K. L., 2004. Antiretrovirals, part 1: overview, history, and focus on protease inhibitors. Psychosomatics 45(3), 262-270.

Yang, R.L, Shi, Y., Hao, G., Li, W., Le, G., 2008. Increasing Oxidative Stress with Progressive Hyperlipidemia in Human: Relation between Malondialdehyde and Atherogenic. Index J. Clin. Biochem. Nutr. 43(3), 154-158.

Zanquetta, M.M., Seraphim, P.M., Sumida, D.H., CipollaNeto, J., Machado, U.F., 2003. Calorie restriction reduces pinealectomy-induced insulin resistance by improving GLUT4 gene expression and its translocation to the plasma membrane. J. Pineal Res. 35, 141-148. 


\title{
Придобивки од третманот со мелатонин и алфа-липоична киселина при лопинавир/ритонавир-предизвикани промени на липидниот и гликозниот статус кај машки албино стаорци
}

\author{
Елиас Адикву*, Брамбаифа Нелсон, Волфе Атубоведиа Обианиме

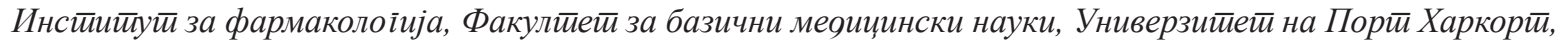 \\ Чоба, Ниіерија
}

Клучни зборови: лопинавир/ритонавир, мелатонин, алфа-липоична киселина, липиден статус, гликоза, стаорци

Примената на лопинавир/ритонавир е поврзана со промени на нивоата на серумските липиди и гликоза. Актуелната студија е дизјанирана со цел да ги истражи ефектите на мелатонин (МТ) и алфа-липоична киселина (ALA) врз лопинавир/ритонавир-предизвиканите промени на серумските нивоа на триглицеридите (TG), вкупниот холестерол (TC), липопротеините со ниска густина (LDL-C), липопротеините со многу ниска густина (VLDL-C) и гликозата (GL) кај машки албино стаорци. Стаорците од првата група, A1 (плацебо-контролирана) и втората група, A2 (третирана со растворувач), беа орално третирани со физиолошки раствор и $1 \%$ етанол, соодветно. Групите B-F, секоја со по 15 стаорци, понатаму беа поделени на 3 подгрупи, секоја со по 5 стаорци. Стаорците во групата В беа третирани орално со MT (10 mg kg-1/ден), ALA (10 mg kg-1/ден) и нивна комбинација, соодветно. Стаорците во група С беа орално третирани со 22,9/5,71; 45,6/11,4 и 91,4/22,9 mg kg-1/денлопинавир/ритонавир, соодветно. Стаорците во групите D-F беа орално третирано со МT (10 mg kg-1/ден), ALA (10 mg kg-1/ден) и комбинирани дози на МТ и ALA, соодветно, пред оралниот третман со дози на лопинавир/ритонавир од 22,9/5,71; 45,6/11,4 и 91,4/22,9 mg kg-1/ ден, соодветно. Сите стаорци беа третирани во текот на 30 денаи на крајот од третманот беа определени серумските нивоа на липидните фракции и гликоза. Третманот со MT и ALA значајно $(\mathrm{p}<0,05)$ ги намали почетните вредности на TG, TC, LDL-C и VLDL-C и GL, но овие параметри беа значајно ( $<0,05)$ зголемени, дозно-зависно, кај стаорците третирани со лопинавир/ритонавир споредено со плацебо-контролираната група. Примената на MT и ALA пред третманот со лопинавир/ритонавир значајно $(\mathrm{p}<0,05)$ ги намали серумските нивоа на TG, TC, LDL-C и VLDL-C и GL споредено со лопинавир/ритонавир-третираните стаорци. Меѓутоа, намалувањата забележани кај стаорците претходно третирани со комбинација на MT и ALA беа значајно ( $<<0,05)$ различни споредено со одделните третмани. Како заклучок, добиените резултати посочуваат дека комбинацијата MT и ALA може да го подобри липидниот и гликозниот статус променет под дејство на лопинавир/ритонавир. 
